\title{
Biocontrol agents in the management of Meloidogyne incognita in tomato
}

\author{
Juliana de Oliveira Silva ${ }^{1^{*}}$ Marcus Vinícius Santana ${ }^{1}$ Leonardo Levorato Freire ${ }^{1}$ \\ Bruno da Silva Ferreira ${ }^{2}$ Mara Rúbia da Rocha ${ }^{1}$
}

${ }^{1}$ Escola de Agronomia, Programa de Pós-graduação em Agronomia, Universidade Federal de Goiás (UFG), Campus Samambaia, 74690-900, Goiânia, GO, Brasil. E-mail: julianadeos13@gmail.com *Corresponding author.

${ }^{2}$ Sellar Análises Agrícolas, Gurupi, TO, Brasil.

\begin{abstract}
Recognized as prominent among the principal pests of tomato crop, the root-knot nematode (Meloidogyne incognita) has generated much study with regards to control methods. This study aimed to assess the efficiency of biological products in decreasing the M. incognita population in tomato. Four experiments were conducted under greenhouse conditions. Two of these experiments had the purpose to determine the efficiency of NemOut ${ }^{\mathrm{TM}}$ (Bacillus subtilis + B. licheniformis + Trichoderma longibrachiatum), and the other two to assess the efficiency of other different biological products in M. incognita management. Tomato plants of the cultivar Santa Cruz Kada Giant were inoculated using 2000 eggs and J2 of M. incognita. In the first two experiments doses corresponding to 0, 4, 6, 8 and 10kg ha ${ }^{-1}$ of NemOut were applied after inoculation. In the second study, the treatments consisted of the use of biological products containing different other biocontrol agents. Assessments were made at 45 and 65 days after inoculation (DAI) to evaluate plant height, fresh shoot and fresh root weigh, gall index and egg mass index, population density and reproduction factor (RF). The NemOut $\mathrm{TM}$ doses reduced the M. incognita population density and RF at 45 DAI. The agent Pochonia chlamydosporia showed greater efficiency in controlling M. incognita on tomato. Biological products and the different doses of NemOut ${ }^{\mathrm{TM}}$ had no influence on the tomato plant development.

Key words: biological control, root-knot nematode, Solanum lycopersicum, opportunistic fungi, Pochonia chlamydosporia.
\end{abstract}

Agentes de biocontrole no manejo de Meloidogyne incognita em tomateiro

RESUMO: O nematoide das galhas (Meloidogyne incognita) é relatado como uma das principais pragas da cultura do tomate, sendo importante o estudo de alternativas para o seu manejo. O presente estudo objetivou avaliar a eficiência de produtos biológicos na redução da população de M. incognita em tomate. Foram conduzidos quatro experimentos em casa de vegetação, dois visando avaliar a eficiência de doses de NemOut ${ }^{\mathrm{TM}}$ (Bacillus subtilis + B. licheniformis + Trichoderma longibrachiatum), e outros dois para avaliar a eficiência de diferentes produtos biológicos no controle de M. incognita. Plantas de tomate Santa Cruz Kada Gigante foram inoculadas com 2000 ovos e J2 de M. incognita. No primeiro estudo foram utilizadas doses equivalentes a 0, 4, 6, 8 e $10 \mathrm{~kg} \mathrm{ha}^{-1}$ de NemOut ${ }^{\mathrm{TM}}$, aplicadas após a inoculação. No segundo estudo os tratamentos constituíram de produtos biológicos com diferentes agentes de biocontrole. As avaliações foram realizadas 45 e 65 dias após a inoculação (DAI), determinando-se altura de plantas, massa fresca da parte aérea e da raiz, índice de galhas e de massas de ovos, densidade populacional e fator de reprodução (FR). Doses crescentes de NemOut ${ }^{\mathrm{TM}}$ reduziram a densidade populacional e o FR de M. incognita, aos 45 DAI. O agente Pochonia chlamydosporia mostrou-se mais eficiente no controle de M. incognita no tomateiro. Os produtos biológicos e as diferentes doses de $\mathrm{NemOut}^{\mathrm{TM}}$ não afetaram o desenvolvimento das plantas de tomate.

Palavras-chave: controle biológico; nematoide de galhas; Solanum lycopersicum, fungos oportunistas, Pochonia chlamydosporia.

\section{INTRODUCTION}

The genus Meloidogyne (GOELDI, 1987) includes the plant nematodes most injurious to vegetables, particularly to tomato crops, causing high harvest losses, mostly in tropical and subtropical agriculture (KIEWNICK \& SIKORA, 2006). Traditionally, the main control technique involves the use of chemical nematicides; however, the negative consequences of these products to the environment and their inefficiency after long-term use have resulted in the prohibition or restrictions on various molecules employed. Therefore, there is an increasing requirement for developing non-chemical alternative methods for the management of the root-knot nematode (HUANG et al., 2016).

One beneficial alternative that is gaining popularity in nematode control is the biological 
control, predominantly utilizing the microorganism groups like the fungi and bacteria already present in the soil biota (CRAWFORD \& CLARDY, 2011). In fact, many microorganisms reveal the capacity to parasitize the egg and juvenile forms and sometimes even adult nematodes.

Species of Bacillus Gaertner interrupts the nematode life cycle by producing toxic metabolites which restrict their mobility and hinder the hatching and juvenile penetration into plant roots (KAVITHA et al., 2007). Trichoderma longibrachiatum Rifai, Purpureocillium lilacinus (Thom) Samson and Pochonia chlamydosporia Zare \& Gams are wellrecognized for their parasitic behavior on exposed eggs and females. They form the base of many commercial products available for the nematode control, as they reveal promising results as effective biological control agents (DALLEMOLE-GIARETTA et al., 2014). They also can release toxic metabolites that prevent the penetration and parasitic multiplication of the nematode. These opportunistic fungi parasitize some of nematode phases whenever they come into contact with them (ANASTASIADIS et al., 2008).

Although, several research studies are available on biological nematode control, there continues to be a dearth of registered biological nematicides. This study aimed at assessing the nematicidal potential of the commercial biological products available, which contain Bacillus spp., Trichoderma longibrachiatum, Paecilomyces lilacinus and Pochonia chlamydosporia, to control the $M$. incognita population in the tomato crop.

\section{MATERIALS AND METHODS}

Under greenhouse conditions, we performed four experiments from March to May 2014 and from October to December 2014. Two of the experiments were done to examine the effect of the different doses of Bacillus licheniformis $+B$. subtilis + Trichoderma longibrachiatum (NemOut ${ }^{\mathrm{TM}}$ ) on decreasing the $M$. incognita population in tomato. The other two experiments were conducted to assess the efficiency of the different commercial products in controlling $M$. incognita in tomato.

The tomato cultivar Santa Cruz Kada Gigante seedlings were grown in a commercial nursery and transplanted 30 days after sowing to $5 \mathrm{~L}$ polyethylene pots filled with substrate. The substrate was a previously sterilized soil and sand in a ratio of 1: 1. Each pot received one transplanted seedling. Five days later, each plant was inoculated with 2000 M. incognita eggs and J2, dispersed in two holes around the plant collar. The inoculum used was obtained from Santa Cruz Kada Gigante tomato plants maintained in a greenhouse for inoculum production.

\section{Effect of NemOut ${ }^{\mathrm{TM}}$ doses on M. incognita on tomato} plants

In the treatments the commercial product NemOut ${ }^{\mathrm{TM}}$ was used (Bacillus licheniformis $+B$. subtilis + Trichoderma longibrachiatum) in five doses of $0,4,6,8$ and $10 \mathrm{~kg} \mathrm{ha}^{-1}$ (corresponding to $0,1.5,2.25,3$ and $3.75 \times 10^{12} \mathrm{CFU}$ ). This product was mixed into the substrate one day after the nematode inoculation. The experimental design was completely randomized with five treatments and five replications. Each experimental plot involved two tomato plants, one in each pot.

At 45 and 65 days after inoculation (DAI), assessment was done on one plant for each period. Shoot length and shoots and roots fresh weigh were evaluated. Roots were staining with Floxin B and the gall index (GI) and egg mass index (EMI) were evaluated, in accordance with the method of TAYLOR \& SASSER (1978).

The nematode population density was assessed after extraction of eggs and $\mathrm{J} 2$ based on the procedure of HUSSEY \& BARKER (1973). Counting was performed under an optical microscope (40x magnification) using a Peters slide. The result was presented as number of eggs and $\mathrm{J} 2 / 10 \mathrm{~g}$ of roots. The reproduction factor (RF) was determined according to OOSTENBRINK (1966).

The findings of this study were submitted to the analysis of variance. Only when significance between the doses was observed, the regression analysis was done. The data were then adjusted for the linear, quadratic and cubic models. The best model was selected based on the significance of regression $(\mathrm{P}<0.05)$ and the coefficient of determination $\left(\mathrm{R}^{2}\right)$.

Efficiency of the biological products for the $M$. incognita management in tomato

Experiments were carried out in a completely randomized design with six treatments and with five replications. The treatments were five biological products plus one control as the treatments viz., Purpureocillium lilacinus (Paecilomyces $\mathrm{JCO}^{\circledR}$, $400 \mathrm{~g}$ tray $^{-1}$ ), Purpureocillium lilacinus (Nemat $^{\circledR}$ WP, 200 $\mathrm{g} \mathrm{ha}^{-1}$ ), Bacillus subtilis isolated QST 713 $\left(\right.$ Serenade $^{\circledR} \mathrm{SC}$, ha $\left.^{-1}\right)$, Pochonia chlamydosporia Pc10 (Rizotec $^{\circledR}, 2.0 \mathrm{~kg} \mathrm{ha}^{-1}$ ), and Bacillus licheniformis + B. subtilis + Trichoderma longibrachiatum $\left(\mathrm{NemOut}^{\circledR}, 7.0 \mathrm{~kg} \mathrm{ha}{ }^{-1}\right)$. The experimental plot included two plants, one per pot. The biological 
products $\mathrm{Nemat}^{\circledR}$ and Paecilomyces $\mathrm{JCO}^{\circledR}$ were diluted prior to being applied onto the seedlings when they were still growing in the trays before being transplanted into the pots. The NemOut ${ }^{\mathrm{TM}}$, Serenade ${ }^{\circledR}$ and Rizotec ${ }^{\circledR}$ products were applied to the soil after dilution in water, close to the plant stem, one day after inoculation with the nematodes, according to manufacturer's recommendations. The treatments involved a single application of each product. One plant was removed on the $45^{\text {th }}$ day and one on the $65^{\text {th }}$ day after inoculation (DAI) and assessed for shoot length, fresh shoot and root weigh, gall and egg mass indexes, nematode population density and reproduction factor, as described before.

Applying the Kolmogorov-Smirnov test the normality of the residues was confirmed while the Levene test was used to ascertain the homogeneity of the variances. When the data failed to fulfill the assumptions of the analysis of variance (Anova), they were transformed using the method proposed by BOX \& COX (1982). The data were submitted to Anova and when significance was observed the means were separated by the Tukey test $(\mathrm{P}<0.05)$.

\section{RESULTS AND DISCUSSION}

No influence was observed in this study of the commercial product NemOut ${ }^{\mathrm{TM}}$ (with Bacillus licheniformis + B. subtilis + Trichoderma longibrachiatum as the constituents) on the variables connected with plant development (plant height, shoot and root fresh weigh). The Bacillus and Trichoderma are better known as plant growth promoters (RESENDE et al., 2004; FORTES et al.,
2007); although, in this study, concurring with the findings of FERNANDES et al. (2014) no increase in the fresh weigh of the tomato plants treated with Trichoderma spp. and Bacillus sp. was noted.

Increase in the $M$. incognita population was observed in Experiment 1; therefore, all the treatments were rated 5.0, according to TAYLOR \& SASSER (1978), for the gall index (GI) and the egg mass index (EMI). Experiment 2 revealed that the GI was between 2.75 and 3.5 at 45 DAI and between 4.25 and 5.0 at 65 DAI while the EMI ranged from 2.12 to 3.0 at 45 DAI and from 2.87 to 4.28 at 65 DAI. These indexes indicated a nematode population rise during the second assessment period; however, no significant difference was observed among the treatments at either of the periods. This increase may be attributed to the plant development, because at 65 DAI the root weigh was higher than at 45 DAI.

The $M$. incognita population density and reproduction factor were affected by the doses of the commercial product constituted by $B$. licheniformis + B. subtilis $+T$. longibrachiatum. Significant regressions were noted only in the evaluations done at 45 DAI in Experiment 1, where the increased dosages of the product caused a linear decline of both the population density and RF (Figure 1). The increased $M$. incognita population development recorded in Experiment 1 may have improved the product efficiency in this experiment (Table 1). The linear reduction reported in the $M$. incognita population density as well as the RF, in response to the increasing doses of $B$. licheniformis $+B$. subtilis $+T$. longibrachiatum in only one experiment, is significant; however, it highlights the necessity for
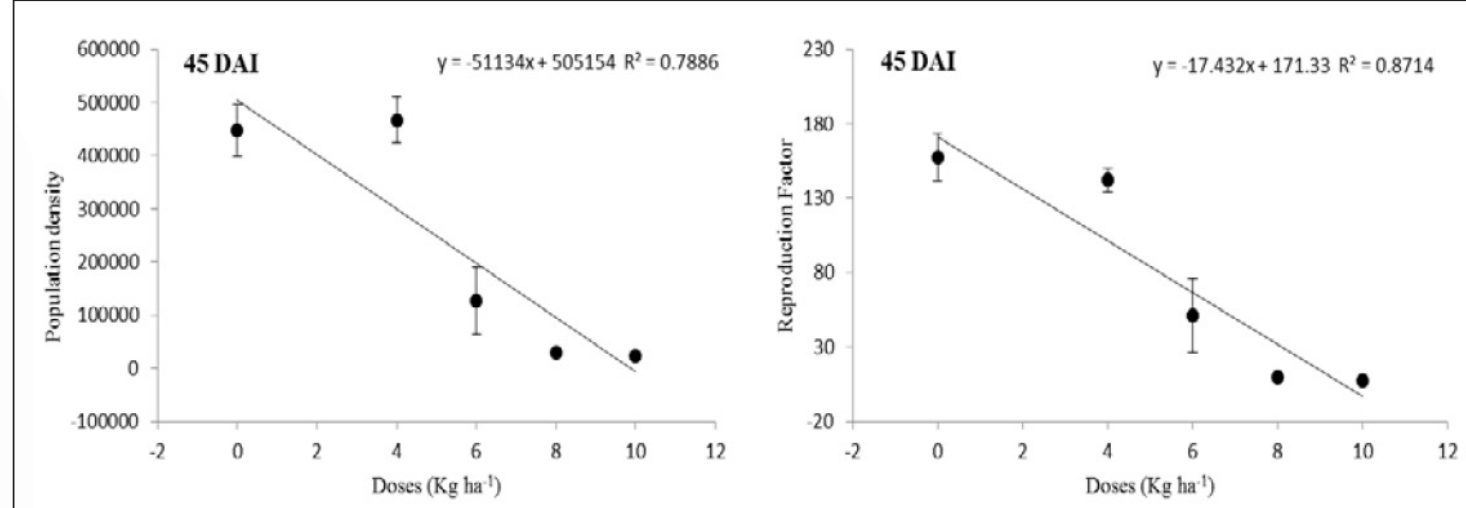

Figure 1 - Population density (eggs and J2/10g of root) and reproduction factor of Meloidogyne incognita in the Santa Cruz Kada Gigante tomato roots submitted to different doses of the product Bacillus subtilis + B. licheniformis + Trichoderma longibrachiatum and evaluated at 45 (DAI). 
Table 1 - Population density (number of eggs and J2 / 10g of root) and reproduction factor (RF) of the tomato roots treated with different Bacillus subtilis + B. licheniformis + Trichoderma longibrachiatum $\left(\right.$ NemOut $\left.{ }^{\mathbb{R}}\right)$ doses in two experiments. Evaluations performed at 45 and 65 days after inoculation (DAI) with M. incognita.

\begin{tabular}{|c|c|c|c|c|}
\hline \multirow{3}{*}{ Doses $(\mathrm{kg} / \mathrm{ha})$} & \multicolumn{2}{|c|}{---------------------Experiment 1--------------------- } & \multicolumn{2}{|c|}{--------------------Experiment 2------------------- } \\
\hline & 45 DAI & $65 \mathrm{DAI}$ & 45 DAI & 65 DAI \\
\hline & \multicolumn{4}{|c|}{ 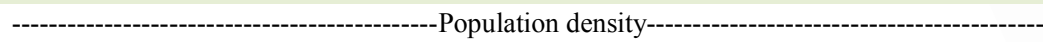 } \\
\hline 0 & 446754.87 & 27598.61 & 324.11 & 3070.24 \\
\hline 4 & 467323.26 & 31387.13 & 625.61 & 13566.02 \\
\hline 6 & 127587.48 & 24964.02 & 473.52 & 12592.29 \\
\hline 8 & 29486.75 & 39088.25 & 191.95 & 4598.13 \\
\hline 10 & 22864.23 & 34408.56 & 372.22 & 23125.42 \\
\hline CV (\%) & 52.54 & 56.51 & 58.65 & 63.96 \\
\hline \multicolumn{5}{|c|}{ - } \\
\hline 0 & 157.54 & 18.27 & 0.13 & 1.71 \\
\hline 4 & 142.14 & 19.94 & 0.24 & 7.87 \\
\hline 6 & 51.27 & 23.36 & 0.15 & 8.94 \\
\hline 8 & 10.11 & 17.98 & 0.06 & 2.75 \\
\hline 10 & 7.48 & 19.75 & 0.19 & 6.10 \\
\hline CV (\%) & 52.78 & 37.59 & 12.17 & 48.13 \\
\hline
\end{tabular}

more investigations on the product efficiency in nematode control on tomato crop.

Products containing a combination of biocontrol agents have become an accepted and more efficient method of pathogen control and; therefore, improved plant growth, because it is probable that in sites where natural biological control occurs, it happens as a consequence of different combinations of many microorganisms (ROBERTS et al., 2005). The biocontrol agents of $B$. subtilis $+B$. licheniformis $+T$. longibrachiatum, that constitute the product used in this study, may have promoted the reduction in the M. incognita population recorded in this study. This is because different agents possess different action mechanisms, which are anticipated to complement nematode control.

Both experiments conducted with the purpose to identify the influence of the different biological products, revealed that the plant growth (evident by the height, fresh shoot and root weigh) was not affected by the treatments. The increased growth induced by Bacillus spp. and P. chlamydosporia that has been reported in many studies (ARAÚJO \& MARCHESI, 2009, MACIÁ-VICENTE et al., 2009) was not recorded in the present study.

In the tomato plants, the $M$. incognita population was affected in Experiment 2 by the different biological products. P. chlamydosporia Pc-10 caused a decline in the population density while the RF determined at $45 \mathrm{DAI}$, showed a significant difference from the control and from the application of $P$. lilacinus WP (Figure 2). In the assessment done at $65 \mathrm{DAI}$, as well as in both the estimations of Experiment 1, no differences were visible among the treatments, with high population densities and RF values being recorded (Figure 2 ).

$P$. chlamydosporia is a fungus highly utilized in the biological control of nematodes, especially the root-knot nematodes, as it is a fungus that parasitizes females and eggs, the later being the most vulnerable stage of this pathogen life cycle. $P$. chlamydosporia caused a decline in the number of $M$. javanica galls and eggs, in tomato plants (DALLEMOLE-GIARETTA et al., 2014) by $40 \%$ and $72.83 \%$, respectively. In the current study, the $M$. incognita in tomato roots was treated with the $P$. chlamydosporia, and its effect was compared with the control, as reported often by different authors (BOURNE \& KERRY, 1999; ATKINS et al., 2003). However, the efficiency of the fungus in parasitizing the eggs present in the soil is dependent on two factors: temperature and developmental stage of the embryo within the egg. The fungus undergoes rapid colonization which occurs in the stages of cell multiplication and embryo development, and the juveniles hatch at temperatures approaching $30^{\circ} \mathrm{C}$; they escape before the egg mass is colonized, because the fungus does not attack the mobile adult nematodes (DALLEMOLE-GIARETTA et al., 2008). With respect to the temperature conditions observed at the time the experiments were carried out (mean 


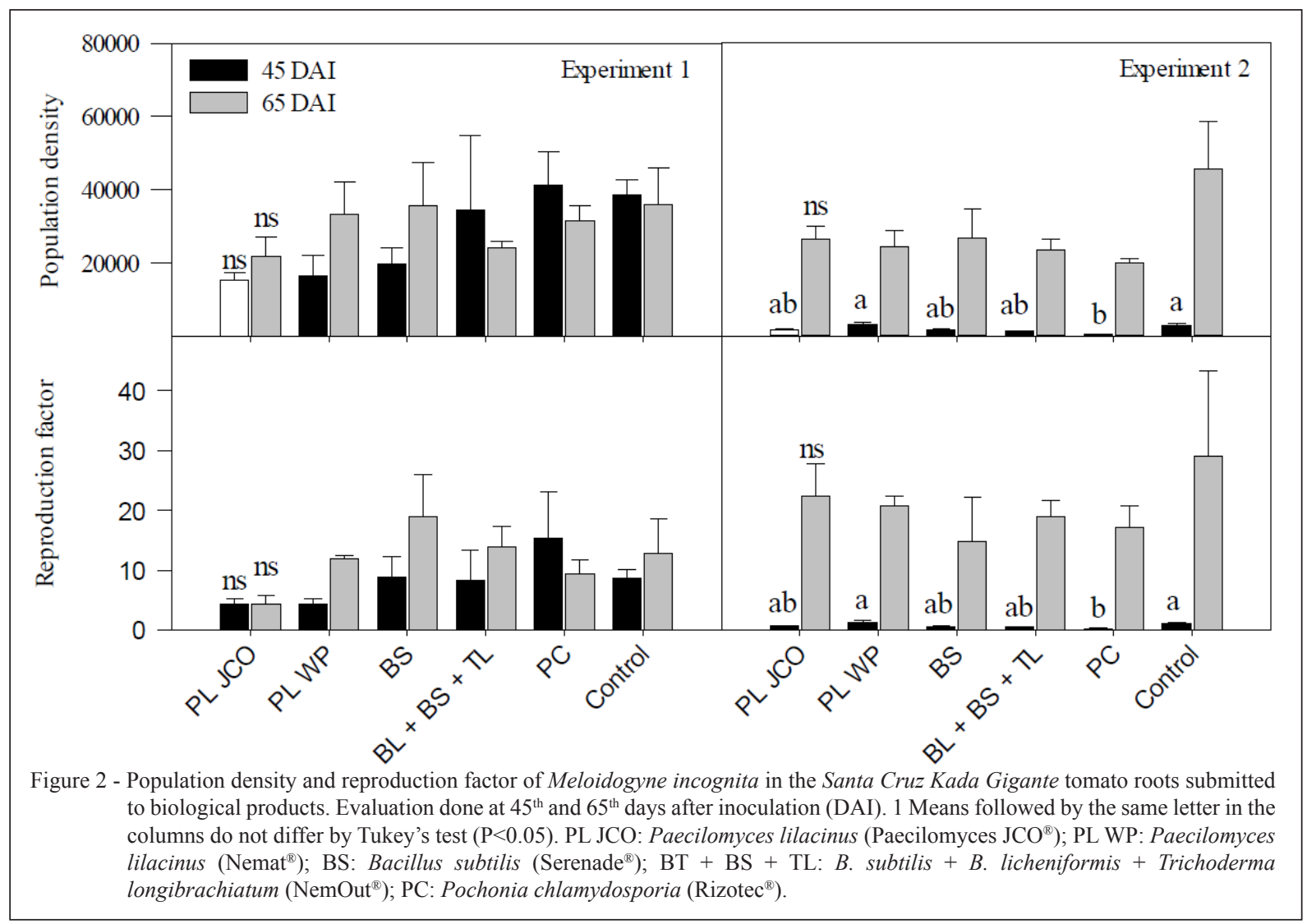

minimum and maximum, about $21^{\circ} \mathrm{C}$ and $35^{\circ} \mathrm{C}$, respectively), it is possible that the efficiency of the fungus in controlling the nematode population was reduced in the other evaluations that were performed.

The most important step is for the biocontrol agent to establish itself in the rhizosphere, in order to facilitate the interaction of the microrganism with the plant. The nutritional content and organic matter present in the soil can hamper this establishment; and consequently, root colonization will not occur. The soil contains organic compounds which form the substrate on which the antagonists can multiply and establish themselves (FREITAS et al., 2003). In the present experiments, the lack of organic matter in the substrate used may have exerted a negative effect on the development of the biocontrol agents tested.

For the biocontrol agents to be effective, the timing of the application is very significant. According to SILVEIRA \& FREITAS (2007), these microorganisms must be added to the soil as early as possible, as the dynamics of the ecosystem that they attempt to invade may hinder their establishment.
RADWAN et al., (2012) reported that the Trichoderma isolates showed positive effects by minimizing the degree of damage caused by $M$. arenaria and $M$. javanica, respectively, when the fungus was applied at an early point in time to the soil. Thus, the biocontrol agent may not have been applied, in this study, at the ideal time to ensure its efficiency.

The establishment and maintenance of these beneficial microorganisms in the soil must be achieved year after year, because in this way biocontrol agents are established and reproducing, thus increasing the soil suppressiveness. Many authors reported that the results from studies using microorganisms are often inconsistent, as these microorganisms fail to always exhibit the same behavioral patterns, either as growth promoters or as pathogen controllers, even when they are subjected to identical testing conditions (CHANWAY et al., 2000; FREITAS et al., 2003).

\section{CONCLUSION}

The tomato plants showed no response in their development to the biological products 
tested. Increasing doses of the commercial product composed of Bacillus licheniformis + B. subtilis + Trichoderma longibrachiatum reduces the population of $M$. incognita in tomato. The agent Pochonia chlamydosporia $P c-10$ caused the $M$. incognita population density and reproduction factor to decline in the tomato crop.

\section{ACKNOWLEDGEMENTS}

To the Coordenação de Aperfeiçoamento de Pessoal de Nível Superior (CAPES) and to Conselho Nacional de Desenvolvimento Científico e Tecnológico (CNPq) for granting the scholarship to authors.

\section{REFERENCES}

ANASTASIADIS, I.A. et al. The combined effect of the application of a biocontrol agent Paecilomyces lilacinus, with various practices for the control of root-knot nematodes. Crop Protection, Guildford, v.27, p.352-361, 2008. Available from: $<$ https://doi. org/10.1016/j.cropro.2007.06.008>. Accessed: Oct. 20, 2016. doi: doi:10.1016/j.cropro.2007.06.008

ARAÚJO, F.F.; MARCHESI, G.V.P. Use of Bacillus subtilis in the control of root-knot nematode and the growth promotion in tomato. Ciência Rural, Santa Maria, v.39, n.5, p.15581561, 2009. Available from: <http://www.scielo.br/scielo. php?script $=$ sci arttext\&pid $=$ S0103-84782009000500039\&lng $=$ pt\&tlng=pt $>$. Accessed: Oct. 20, 2016. doi: 10.1590/S010384782009000500039 .

ATKINS, S.D. et al. Development of a new management strategy for the control of root-knot nematodes (Meloidogyne spp.) in organic vegetable production. Pest Management Science, West Sussex, v.59, n.2, p.183-189, 2003. Available from: <http:// onlinelibrary.wiley.com/doi/10.1002/ps.603/abstract>. Accessed: Oct. 15, 2016. doi: 10.1002/ps.603.

BOURNE, J.M.; KERRY, B.R. Effect of the host plant on the efficacy of Verticillium chlamydosporium as a biological control agent of root-knot nematodes at different nematode densities and fungal application rates. Soil Biology and Biochemistry, Oxford, v.31, n.1, p.75-84, 1999. Available from: <http://www.sciencedirect. com/science/article/pii/S0038071798001072?via\%3Dihub>. Accessed: Sep. 21, 2016. doi: 10.1016/S0038-0717(98)00107-2.

BOX, E.P.; COX, D.R. An analysis of transformations revisited, rebutted. Journal of the American Statistical Association, Alexandria, v.77, n.377, p.209-2010, 1982.

CHANWAY, C.P. et al. Endophytic colonization and field responses of hybrid spruce seedlings after inoculation with plant growthpromoting rhizobacteria. Forest Ecology and Management, Amsterdam, v.133, n.1-2, p.81-88, 2000. Available from: $<$ https:// doi.org/10.1016/S0378-1127(99)00300-X>. Accessed: Out. 20, 2016. doi: $10.1016 / \mathrm{S} 0378-1127(99) 00300-\mathrm{X}$.

CRAWFORD, J.M.; CLARDY, J. Bacterial symbionts and natural products. Chemical Communications, Cambridge, v.47, n.27, p.7559-7566, 2011. Available from: <https://www.ncbi.nlm.nih. gov/pmc/articles/PMC3174269/>. Accessed: Aug. 16, 2016. doi: 10.1039/c1cc11574j.
DALLEMOLE-GIARETTA, R. et al. Effect of different rates of Pochonia chlamydosporia var. chlamydosporia chlamydospores on Meloidogyne javanica control. Nematologia Brasileira, Piracicaba, v.32, n.4, p.327-332, 2008. Available from: $<$ https://www. researchgate.net/publication/238770911_Efeito_da_Concentracao_de_ Clamidosporos_de_Pochonia_chlamydosporia_var_chlamydosporia_ no_Controle_de_Meloidogyne_javanica $>$. Accessed: Aug. 15, 2016.

DALLEMOLE-GIARETTA, R. et al. Soil amendment with substrate containing mycelium and conidia of Pochonia chlamydosporia for the management of Meloidogyne javanica. Ciência Rural, Santa Maria, v.44, n.4, p.629-633, 2014. Available from: <http://dx.doi. org/10.1590/S0103-84782014000400009>. Accessed: Sep. 15, 2016. doi: 10.1590/S0103-84782014000400009.

FERNANDES, R.H. et al. Pochonia chlamydosporia and Bacillus subtilis on the control of Meloidogyne incognita and M. javanica in tomato seedlings. Bioscience Journal, Uberlândia, v.30, n.1, p.194200, 2014. Available from: <http://www.seer.ufu.br/index.php/ biosciencejournal/article/view/18025>. Accessed: Aug. 17, 2016.

FORTES, F.O. et al. Root induction from microcutting of an Eucalyptus sp. clone by Trichoderma spp. Revista Árvore, Viçosa, v.31, n.2, p.221-228, 2007. Available from: <http://dx.doi. org/10.1590/S0100-67622007000200004>. Accessed: Aug. 15, 2016. doi: $10.1590 /$ S0100-67622007000200004.

FREITAS, S.S. et al. Growth enhancement of lettuce by rhizobacteria. Revista Brasileira de Ciência do Solo, Viçosa, v.27, n.1, p.61-70, 2003. Available from: <http://dx.doi.org/10.1590/ S0100-06832003000100007>. Accessed: Aug. 15, 2016. doi: 10.1590/S0100-06832003000100007.

HUANG, W.-K. et al. Testing various biocontrol agents against the root-knot nematode (Meloidogyne incognita) in cucumber plants identifies a combination of Syncephalastrum racemosum and Paecilomyces lilacinus as being most effective. Biological Control, Orlando, v.92, p.31-37, 2016. Available from: <https:// doi.org/10.1016/j.biocontrol.2015.09.008>. Accessed: Oct. 20, 2016. doi: 10.1016/j.biocontrol.2015.09.008.

HUSSEY, R.S.; BARKER, K.R. A comparison of methods of collecting inocula of Meloidogyne spp. including a new technique. Plant Disease Reporter, St. Paul, v.57, p.1.025-1.028, 1973. Available from: <http://agris.fao.org/agris-search/search. do? recordID=US201303126127>. Accessed: Jul. 08, 2016.

KAVITHA, J. et al. Field application of Pseudomonas fluorescens, Bacillus subtilis and Trichoderma viride for the control of Meloidogyne incognita in sugarbeet. Journal of Biological Control, Bangalore, v.21, n.2, p.211-215, 2007. Available from: $<$ https://doi.org/10.18311/jbc/2007/3851>. Accessed: Aug. 16, 2016. doi: $10.18311 / \mathrm{jbc} / 2007 / 3851$.

KIEWNICK, S.; SIKORA, R.A. Biological control of the rootknot nematode Meloidogyne incognita by Paecilomyces lilacinus strain 251. Biological Control, Orlando, v.38, p.179-187, 2006. Available from: <https://doi.org/10.1016/j.biocontrol.2005.12.006>. Accessed: Aug. 15, 2016. doi: 10.1016/j.biocontrol.2005.12.006.

MACIÁ-VICENTE, J.G. et al. Colonization of barley roots by endophytic Fusarium equiseti and Pochonia chlamydosporia: effects on plant growth and disease. Annals of Applied Biology, Warwickshire, v.155, n.3, p.391-401, 2009. Available from: <http:// onlinelibrary.wiley.com/doi/10.1111/j.1744-7348.2009.00352.x/pdf $>$. Accessed: Aug. 17, 2016. doi: 10.1111/j.1744-7348.2009.00352.x. 
TENBRINK, M. Major characteristic of relation between nematodes and plants. Wageningen: Mededelingen Landbouwhogeschool, v.66, n.4, p.1-46, 1966. Available from: <edepot.wur.nl/404303>. Accessed: Jul. 08, 2016.

RADWAN, M.A. et al. Biological control of the root-knot nematode, Meloidogyne incognita on tomato using bioproducts of microbial origin. Applied Soil Ecology, Amsterdam, v.56, n. 1, p.58-62, 2012 Available from: <https://doi.org/10.1016/j.apsoil.2012.02.008>. Accessed: Aug. 15, 2016. doi: 10.1016/j.apsoil.2012.02.008.

RESENDE, M.L. etal.Corn seed inoculation using Trichoderma harzianum as a growth promoter. Ciência Agrotécnica, Lavras, v.28, n.4, p.793-798, 2004 Available from: <http://dx.doi.org/10.1590/S1413-70542004000400010>. Accessed: Sep. 15, 2016. doi: 10.1590/S1413-70542004000400010.
ROBERTS, D.P. et al. Biocontrol agents applied individually and in combination for suppression of soilborne diseases of cucumber. Crop Protection, Amsterdam, v.24, n.2, p.141155. 2005. Available from: <https://doi.org/10.1016/j. cropro.2004.07.004>. Accessed: Sep. 13, 2016. doi: 10.1016/j. cropro.2004.07.004.

SILVEIRA, A.P.D.; FREITAS, S.S. Microbiota do solo e qualidade ambiental. Campinas: Instituto Agronômico, 2007. 317p. Available from: <https://pt.scribd.com/document/7981055/Livro-MicrobiotaDo-Solo-e-Qualidade-Ambiental>. Accessed: Sep. 13, 2016.

TAYLOR, A.L.; SASSER, J.N. Biology, identification and control of root-knot nematodes (Meloidogyne species). Raleigh: North Caroline State Un. Graphics, 1978. 111p. 